\title{
An Analysis of the Financial Attractiveness of Electric Mobility for a Holding of the Brazilian Electric Sector
}

\author{
Guilherme de A. Dantas*, Roberto Brandão*, Nivalde J. de Castro*, \\ Rubens Rosental*, Alexandre C. Lafranque**
}

\section{Resumo}

É possível afirmar que nas próximas décadas mudanças nos sistemas de propulsão dos veículos com vistas a tornar os mesmos mais eficientes estarão diretamente associadas à adoção de motores elétricos a serem alimentados por energia da rede elétrica. A transição para um novo paradigma tecnológico no setor de transportes será condicionada pela instalação em larga escala de postos de recarga de veículos elétricos. A primeira vista, o desenvolvimento de infraestrutura de recarga de veículos elétricos e o aumento da demanda por energia elétrica parecem representar oportunidades de negócios atrativas para empresas do setor elétrico. Porém, a comprovação desta hipótese requer um exame mais minucioso das possibilidades de auferir ganhos financeiros com este negócio. $\mathrm{O}$ objetivo deste artigo é justamente examinar a atratividade da mobilidade elétrica para empresas do setor elétrico brasileiro. As peculiaridades da frota brasileira de veículos leves, com a alta participação dos veículos flex fuel na frota total e a ausência de incentivos fiscais para facilitar a compra de veículos elétricos, fazem com que a expansão dos modelos elétricos não ocorra de forma acelerada. Desta forma, as projeções do consumo para os veículos elétricos mostram que a comercialização de energia para a mobilidade elétrica não devera ser um negócio relevante no médio prazo. Por outro lado, foi apontado que os modelos de mercado delimitam os modelos de negócios a ser implantados. Neste contexto, o Brasil tende a adotar um modelo apresentando um traço mais regulado, corroborando as últimas medidas tomadas pelo governo. Contudo, como a maior parte do investimento está associado aos equipamentos da recarga residencial, pode se concluir que independente do modelo de negócio ser importante para a empresa ou não, sendo que no modelo liberalizado ainda há um risco inerente ao investimento para o empreendedor.

Palavras Chave: veículos elétricos, infraestrutura de recarga, regulação, modelo de negócios, atratividade financeira

\begin{abstract}
It can be argued that in the coming decades, changes in vehicle propulsion systems in order to make them more efficient will be directly associated with the adoption of electric motors that will be powered by the electrical network. The transition to a new technological paradigm in the transportation sector will be conditioned by the large-scale installation of electric vehicle charging stations. At first glance, the development of an infrastructure for recharging electric vehicles and the increase in electricity demand seem to present attractive business opportunities for companies in the electricity sector. However, proving this hypothesis requires a closer examination of the possibilities of obtaining financial gain from this business. This paper's objective is precisely to examine the attractiveness of electric mobility for companies in the Brazilian electricity sector. The unique characteristics of the Brazilian light vehicle fleet, with the high share of flex
\end{abstract}


fuel vehicles in the total fleet and the lack of tax incentives to facilitate the purchase of electric vehicles prevent the expansion of electric models from occurring at an accelerated rate. Thus, the consumption projections for electric vehicles show that selling energy for electric mobility will not be a relevant business in the medium term. On the other hand, it was pointed out that market models define the business models to be implemented. In this context, Brazil tends to adopt a model presenting a more regulated character, corroborating the latest measures taken by the government. However, as most of the investment is associated with the residential recharging equipment, it can be concluded that, regardless of whether or not the business model is important for the company, in the liberalized model, there is still an inherent risk to investment for the entrepreneur.

Keywords: electric vehicles, infrastructure for recharging, regulatory, business model, financial attractiveness

Área ABEIN: Área 4 - Redes e sistemas urbanos, regionais e nacionais; 4.1 Economias de Redes

\section{JEL: L91 Transportation: general}

* Grupo de Estudos do Setor Elétrico do Instituto de Economia da Universidade Federal do Rio de Janeiro (GESEL-IE-UFRJ)

** Engenho Pesquisa e Consultoria 


\section{Introduction}

Currently, approximately $20 \%$ of the demand for primary energy resources belongs to the transportation sector. Since oil products represent about $95 \%$ of all consumed energy, it is understandable why this sector accounts for $25 \%$ of greenhouse gas emissions from the energy sector and causes environmental impacts at a local level (IEA, 2012a, 2013). As the light vehicle fleet is expected to double between 2010 and 2035 and road transport loads will experience high growth, maintaining the current energy paradigm will result in a $1.3 \%$ average annual growth rate in the transportation sector's energy demand over the next 20 years (IEA, 2012b). It is thus clear that this trajectory is incompatible with the need to minimize environmental impacts.

Since light vehicles account for $40 \%$ of energy demand in the transportation sector (IEA, 2013), there is a obvious need for technological changes that reduce the light vehicle fleet's consumption of oil products ${ }^{1}$. As incremental innovations ${ }^{2}$ tend not to be sufficient, the technological paradigm of the light vehicle fleet's propulsion system must be replaced with the spread of electric vehicles. In this sense, even though the change is discreet, hybrid electric vehicles have been included in the global vehicle fleet since the early 2000s (MIDLER and BEAUME, 2010; DIJK et al, 2013). These represent the beginning of the technological innovation and diffusion process that also includes plug-in hybrid electric vehicles ${ }^{3}$ and battery-operated electric vehicles. It can be argued that in the coming decades, changes in vehicle propulsion systems in order to make them more efficient will be directly associated with the adoption of electric motors that will be powered by the electrical network (IEA, 2011; DIAS et al, 2014; EPE, 2014).

The transition to a new technological paradigm in the transportation sector will be conditioned by the large-scale installation of electric vehicle charging stations, in order to reduce consumers' negative perception of electric models (EGBUE and LONG, 2012). At first glance, the development of an infrastructure for recharging electric vehicles and the increase in electricity demand seem to present attractive business opportunities for companies in the electricity sector. However, proving this hypothesis requires a closer examination of the possibilities of obtaining financial gain from this business. This attractiveness depends on the penetration rate of electric vehicles in the fleet, the typology of these vehicles, their recharging standard, and the business models that can be implemented. It is therefore necessary to consider the characteristics and prospects of the light vehicle fleet, as well as the regulatory guidelines in effect.

In the case of Brazil, considering the large-scale use of ethanol in the light vehicle fleet ${ }^{4}$, it is possible to forecast that the penetration of electric vehicles in the fleet will occur at a moderate pace, and that PHEVs will predominate. Thus, the EPE (2014) estimates that the technological transition in the Brazilian automotive industry will happen incrementally; hybrid vehicles will be the first to enter the fleet, while pure electric

\footnotetext{
1 Most developed countries are already applying increasingly stringent standards for vehicle energy efficiency to limit vehicle dependence on fossil fuels (ICCT, 2007, WILLS and LA ROVERE, 2010).

${ }^{2}$ Innovations in internal combustion vehicles would be able to reduce about $30 \%$ of their power consumption (IEA, 2009). However, this reduction in consumption is likely to be mitigated by the trend of larger vehicles' increased participation in the fleet of developing countries.

${ }^{3}$ Plug-in hybrid electric vehicles can be seen as an intermediate stage in the transition from vehicles powered by internal combustion to purely electric vehicles. Since they are equipped with an internal combustion engine, their autonomy is not limited by the ability to store energy in a battery. On the other hand, they can be supplied from the electric grid. They are thus contrasted with hybrid electric vehicles, which only charge their batteries with an internal combustion engine during operation.

4 According to the IEA (2013), over 90\% of energy demand in the Brazilian transportation sector focuses on road transport. In this context, in 2011, the demand for ethanol by light vehicles accounted for over $30 \%$ of the final demand for fuel.
} 
vehicles will only enter the fleet in 2025. It is estimated that in 2030, $8 \%$ of licensed light vehicles will be electric hybrids and $2 \%$ will be pure electric (EPE, 2014).

At the same time, the Brazilian electricity sector displays restricted liberalization, especially at the level of retail marketing. Therefore, it is highly questionable that electricity sales will constitute a business for companies in the sector. In turn, vehiclecharging activity tends to be regulated.

This paper's objective is precisely to examine the attractiveness of electric mobility for companies in the Brazilian electricity sector. For this to be possible, it will test the hypothesis that electric vehicles represent a small portion of the Brazilian demand for electricity and, therefore, the marketing of energy for these vehicles will not be an attractive business. Simultaneously, the economic attractiveness of investment in charging infrastructure will be evaluated, considering the Brazilian regulatory assumptions and a low penetration rate of electric vehicles in the light vehicle fleet.

This paper is divided into five sections, in addition to this introduction. Section 1 presents the elements sustaining the argument that the spread of electric vehicles tends to be a reality for the coming decades. The second part of the work is devoted to examining the different types of recharging infrastructures, as well as possible regulatory models and associated businesses. Section 3 describes the main characteristics of the Brazilian light vehicle fleet and the regulatory framework of the Brazilian electricity sector. The fourth section is dedicated to constructing the scenarios that will serve as a foundation for analyzing the economic attractiveness of the respective investment. Finally, in Section 5, the results of the work are presented.

\section{1 - The Importance of and Obstacles to the Spread of Electric Vehicles}

According to the IEA (2011), electric vehicles store energy in batteries in order to use it in electric motors for the propulsion of the vehicles. This energy can be derived from the electrical system and/or regenerative braking. According to Smith (2010), since the electric vehicle does not require a clutch or a transmission system, and because it is very efficient at all speeds (mainly when starting the engine), the electric vehicle is three times more efficient than a traditional vehicle and up to two times more efficient than a hybrid vehicle. It is therefore possible to understand these vehicles' importance for reducing greenhouse gas emission, especially when the power supplied by the network comes from sources with reduced carbon intensity.

The assertion that $\mathrm{PHEVs}^{5}$ and $\mathrm{BEVs}^{6}$ are more efficient is supported by observing the energy consumption data of these electric vehicles; the performance of a BEV ranges from 5 to $10 \mathrm{~km} / \mathrm{kWh}$, while a PHEV would be able to cover somewhere around 9 $\mathrm{km} / \mathrm{kWh}$ in the depletion mode (Borba, 2012). While the vehicles entering the market present more modest figures, the values are still quite considerable. According to BARAN (2012), the Nissan Leaf $\mathrm{BEV}^{7}$ covers $4.7 \mathrm{~km} / \mathrm{kWh}$, which is equivalent to $42 \mathrm{~km} / \mathrm{l}$ of gasoline. In turn, the Chevrolet Volt ${ }^{8}$ is a series REEV able to go $4.4 \mathrm{~km} / \mathrm{kWh}$ in the electricity mode, i.e., equivalent to $39.5 \mathrm{~km} / \mathrm{l}$ of gasoline. Given that the average performance of an internal combustion vehicle is equivalent to approximately 10.5 kilometers per liter of gasoline, the importance of integrating electric vehicles into the fleet in order to make it more efficient becomes clear.

\footnotetext{
${ }^{5} \mathrm{PHEV}=$ plug-in hybrid electric vehicle.

${ }^{6} \mathrm{BEV}=$ battery electric vehicle.

${ }^{7}$ Vehicle equipped with an $80 \mathrm{~kW}$ electric motor and lithium ion battery with a capacity of $24 \mathrm{kWh}$.

${ }^{8}$ This REEV has a $111 \mathrm{~kW}$ electric motor and a lithium ion battery with a capacity of $16 \mathrm{kWh}$.
} 
A corollary of electric vehicles' increased efficiency is the lower supply cost of BEV and PHEV in relation to conventional vehicles with internal combustion engines. As an illustration, estimates conducted by BORBA (2012) for Rio de Janeiro in March 2012 indicate that the supply for a BEV would cost $4.6 \mathrm{cUSD} / \mathrm{km}$, while the supply for a conventional internal combustion vehicle would cost $14.4 \mathrm{cUSD} / \mathrm{km}$ if fueled with gasoline and $13.9 \mathrm{cUSD} / \mathrm{km}$ if the tank is filled with ethanol ${ }^{9}$. A PHEV operating in depleted load mode would have an electricity energy cost of $2.1 \mathrm{cUSD} / \mathrm{km}$ and 3.1 cUSD $/ \mathrm{km}$ respectively for the configurations in series and in parallel. However, a PHEV run on gasoline would have an expenditure of $8.2 \mathrm{cUSD} / \mathrm{km}$ in parallel configuration and $7.2 \mathrm{cUSD} / \mathrm{km}$ in series configuration ${ }^{10}$.

It is important to mention that the benefits of electric vehicles are not limited to higher efficiency levels. Recharging from the grid enables the adoption of new alternatives to the energy system that can result in a large change in the current technological paradigm. At first, the entry of these vehicles allows a reduction in the electrical system's excess capacity to the extent that they are recharged outside peak times. Over a longer time horizon, it becomes clear that the links between electric vehicles and the network will have a two-way flow of energy and, consequently, the vehicles will no longer be mere energy consumers (KEMPTON and TOMIĆ, 2005).

On the other hand, the issue of proper energy storage is not a well-equated question and this difficulty with the electrochemical storage of energy remains one of the major obstacles in the diffusion of these vehicles. Thus, the autonomy of these vehicles is relatively limited in comparison to traditional internal combustion vehicles. For example, the Nissan Leaf has a range of $116 \mathrm{~km}$ while the Volt has a range of $56 \mathrm{~km}$ in electricity mode (BARAN, 2012). Typically, a BEV with a 22-24 $\mathrm{kWh}$ battery has a range of between 125 and $150 \mathrm{~km}^{11}$. In turn, the autonomy of a REEV vehicle ${ }^{12}$ using only electricity is between 56 and $160 \mathrm{~km}$, reaching around $500 \mathrm{~km}$ when the use of liquid fuels is also considered.

Most consumers point out that these vehicles' lower degree of autonomy is a disadvantage. However, this issue should be considered in perspective. This assumption is supported examining the average daily distances traveled by a light vehicle. As an illustration, this distance in the US is in the order of $50 \mathrm{~km}$ (IEA, 2012a). Since the USA has the largest average distances traveled and, even there, the current autonomy of BEVs would be enough to get around within the city limits, it is clearly more an issue of user perception than a real problem.

In any case, together with the need to reduce the cost of batteries to make electric vehicles competitive, the development of a charging infrastructure is a prerequisite for the effective dissemination of electric vehicles (NATIONAL RESEARCH COUNCIL, 2013). This essentiality results from the fact that it is imperative to reduce the users' negative perception of the vehicle's autonomy, while at the same time enabling the use of these vehicles in transportation that goes beyond the urban perimeter.

2 - Recharging Infrastructure and Regulatory Models

2.1 - Types of Infrastructure

\footnotetext{
${ }^{9}$ Assuming a nominal exchange rate of $1 \mathrm{USD}=1.95 \mathrm{R} \$$ for the year 2012, pursuant to the WORLD BANK (2014).

${ }^{10}$ If the vehicle is fueled by ethanol, the cost would be $\mathrm{R} \$ 0.16 / \mathrm{km}$ for vehicles in series and $\mathrm{R} \$ 0.18$ for the parallel configuration.

${ }^{11}$ The use of batteries with a greater capacity would allow BEVs to have a degree of autonomy close to that of internal combustion vehicles. For example, the Tesla S, with an $85 \mathrm{kWh}$ battery, has a range of $480 \mathrm{~km}$. The big question is the resulting incremental cost of choosing technologies with a greater capacity.

${ }^{12}$ REEV = Range extended electric vehicle.
} 
In contrast to the fueling of vehicles with internal combustion engines that occurs exclusively in service stations, there are many ways to recharge the electric car (XU et al, 2013). When analyzing these different possibilities, it is important to consider that the time required to recharge an electric car is a very important variable for users, and this time is a function not only of the technical characteristics of the car and the battery, but also of the service station.

The most common recharging method is the conductive method, which is a physical connection between the car and the supply point (BORBA, 2012) ${ }^{13}$. This connection may occur at different voltage levels. In general, Level I corresponds to the use of $110 \mathrm{~V}$ AC residential outlets, while Level II is considered as the standard recharge via outlets with a voltage of between 220 and $240 \mathrm{~V}$, with an alternating current of up to $80 \mathrm{~A}^{14}$ (SAE, 2012). This recharging can occur in both private locations (residences and commercial buildings) as well as public stations (BORBA, 2012). It should be noted that Level II recharging can require technical adjustments ${ }^{15}$ in order to enable the delivery of higher power levels, directly impacting the cost of installing a recharging station.

In turn, Level III involves rapid recharging with voltages that can reach up to $500 \mathrm{~V}$ and a current of up to 200A. In this case, the current supplied by the post can either be alternating or continuous ${ }^{16}$ (SAE, 2012). The technical characteristics of Level III are thus incompatible with a residential recharge, because it involves much higher voltages than those available in residential areas, along with requiring a three-phase installation (in the case of AC outlets).

Based on these data and considering the vehicles' characteristics, it is possible to estimate charging time. Figure 1 shows the recharging time for some models, and it is clear that there is a greater recharging time for the Nissan Leaf, which, as a BEV, has a battery with a greater storage capacity, in contrast to other models, which are PHEV.

\footnotetext{
${ }^{13}$ There is also the inductive charging method, which is based on electromagnetic induction, i.e., it does not involve any physical connection between the car and the charging station. There are research projects aimed at recharging the electric car without the presence of a wired connection through induction. However, these projects are still in the early stages of development (NATIONAL RESEARCH COUNCIL, 2013). In addition to the inductive and conductive model, vehicles can also be recharged by battery exchanges and the Redox Flow process, where the battery is recharged by a chemical process.

${ }^{14}$ In general, the current is limited to $40 \mathrm{~A}$.

${ }^{15}$ The adoption of Level II requires some changes to the infrastructure, such as the exchange of cables and circuit breakers, especially when the choice is made for higher currents.

${ }^{16}$ The advantage of recharging with continuous current is that it allows higher energy levels to be supplied, which further reduces the time needed to recharge the car (BULLIS, 2012).
} 
Figure 1: Recharging Time as a Function of Recharging Level and Battery Type ${ }^{17}$

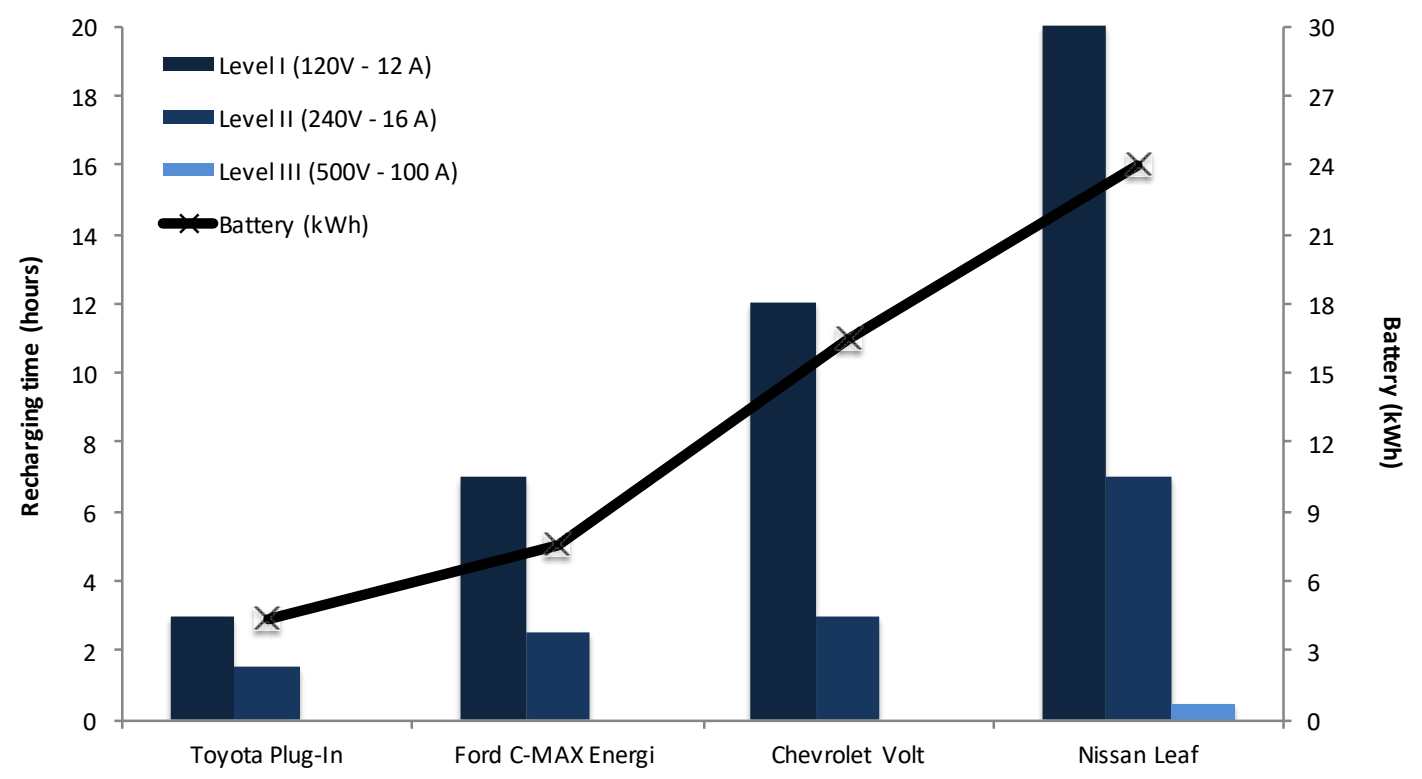

Source: The authors.

Figure 1 indicates that the Level I recharge may be sufficient for PHEVs in the case of a residential recharge, since their batteries' lower capacity implies less refueling time. However, charging at Level I for BEVs should be considered with caution, because the recharge time is very high, exceeding 20 hours for the Nissan Leaf (NATIONAL RESEARCH COUNCIL, 2013). Its technical characteristics thus imply a slow recharge, a fact that is especially relevant in the absence of an infrastructure dedicated to electric car recharging. This type of recharging only applies to locations where the vehicle will be stationary for a relatively long time, such as at home or at the workplace.

On the other hand, Level II offers the full recharging of pure electric car batteries and plug-in hybrids during shorter periods of time. As an illustration, the recharging time of the Nissan Leaf at Level II is 7 hours. From these data, it can be concluded that the Level II recharge is sufficient to meet the recharging needs of a BEV in order to ensure the users' needs and, therefore, it has become the standard among the new BEV models.

Level III enables the rapid recharging of cars, allowing, for example, the battery of the Nissan Leaf to be $80 \%$ recharged in only half an hour. It is therefore understandable why they are usually installed in public areas, with a view to developing public recharging networks.

In addition to the characteristics of electric vehicles entering into the fleet and user preferences, a central issue in defining the type of infrastructure to be implemented is the investment cost. These costs are not restricted to actual stations per se, but also include the investments necessary to adapt the network where the energy flows, the labor cost of the manual work, as well as various operating and maintenance costs. Thus, Table 2 comprehensively summarizes the different costs associated with the investments to be made in electric car recharging stations, according to the recharging level. On the one hand, capital expenditures are estimated, adding the cost of the recharging equipment and

\footnotetext{
${ }^{17}$ It is important to emphasize that the recharge times stated here correspond to the $100 \%$ charge of the vehicle battery, and it therefore the maximum expected charging time. Since typical daily use is less than the BEVs' battery capacity and because users normally charge their vehicles every day, the charging time is less, according to battery's initial state.
} 
the various components to be installed, in addition to the planning and installation of this equipment (ETEC, 2010; SCHROEDER and TRABER, 2012; PLUG IN AMERICA, 2014). On the other hand, the estimated annual operating and maintenance costs account for about $10 \%$ of the initial investment, according to SCHROEDER and TRABER (2012).

Table 1: Estimation of recharging infrastructure costs

\begin{tabular}{|c|c|c|c|c|c|}
\hline & & Level I & $\begin{array}{c}\text { Level II } \\
\text { (Private) }\end{array}$ & $\begin{array}{l}\text { Level II } \\
\text { (Public) }\end{array}$ & $\begin{array}{c}\text { Level III } \\
\text { (CHAdeMO) }\end{array}$ \\
\hline \multirow{4}{*}{ CAPEX (USD) } & $\begin{array}{l}\text { Recharging } \\
\text { equipment }\end{array}$ & - & 776 & 2,730 & 27,021 \\
\hline & $\begin{array}{l}\text { Technical } \\
\text { adaptations of the } \\
\text { network }\end{array}$ & - & 361 & 690 & 1,411 \\
\hline & $\begin{array}{l}\text { Planning and } \\
\text { installations }\end{array}$ & - & 790 & 4,680 & 5,620 \\
\hline & $\begin{array}{l}\text { Administrative } \\
\text { costs }\end{array}$ & - & 385 & 465 & 465 \\
\hline $\begin{array}{l}\text { TOTAL CAPEX } \\
\text { (USD) }\end{array}$ & & - & 2,312 & 8,565 & 34,517 \\
\hline OPEX (USD) & $\begin{array}{l}\text { Total costs, } \\
\text { considering } 10 \% \text { of } \\
\text { the initial } \\
\text { investment }\end{array}$ & - & 231 & 857 & 3,452 \\
\hline
\end{tabular}

Sources: ETEC (2010), SCHROEDER and TRABER (2012), PLUG IN AMERICA

(2014).

Within the capital expenditures, the cost of recharging equipment was estimated according to an international comparison of current market prices (ETEC, 2010; SCHROEDER and TRABER, 2012; PLUG IN AMERICA, 2014). Then, the cost of the devices that need to be installed in order to technically adapt the network upon introducing the recharging equipment was evaluated ${ }^{18}$. Thirdly, the costs for installing and planning the recharging equipment were estimated ${ }^{19}$. The different administrative authorizations to be granted in order to allow the construction of the recharging equipment were also considered (ETEC, 2010).

Table 1 thus shows the higher cost of rapid recharge stations. While the initial investment for residential recharging points is close to USD 2,300, the Level III points of direct current are up to USD $34,500^{20}$. Thus, considering the high costs associated with developing an infrastructure for rapid recharging, these investments are a strategic

\footnotetext{
${ }^{18}$ These devices include electrical panels, circuit breakers, and cables to be installed along with the recharging equipment itself.

${ }^{19}$ It is important to remember that recharging station installation costs are due to the technical adaptation needed for the grid. For example, while Level II does not require many electrical engineering modifications, the high power involved in Level III connections require a thorough adaptation of the network: AC/DC drive installations for stations that deliver direct current, adapting transformers, etc. Therefore, installation costs are higher for Level III stations.

${ }^{20}$ The estimated investments for Level III stations correspond to those of DC stations. This station's high cost is explained by the need to install an AC/DC converter inside the station. This is because the network provides an alternating current and, therefore, it is necessary to install equipment capable of converting energy into direct current at the output of the charging station.
} 
decision that should occur in a planned manner in order for the development of the electric vehicle recharging infrastructure to take place in an optimal manner.

Since cars are parked more than $90 \%$ of the time (IPI, 2011), it is plausible to assume that for people who use vehicles only within the city limits, recharging at work parking lots and residential locations is sufficient (XU et al., 2013). This hypothesis has been supported by electric mobility projects that have been implemented in different regions. For example, data from the EV Project implemented in the US indicate that approximately $85 \%$ of recharges occur at home (ECOTALITY, 2013).

In any case, it is important to highlight the importance of diversity in types of recharging stations because different types of user demand have to be considered. In this sense, the presence of Level III recharging points for recharging vehicles that are going to travel long distances is justified. In the case of the EV Project, the public Level III recharging points have been used 15 times more frequently than the public Level II recharging points (ECOTALITY, 2013). This result confirms the users' concern with recharging time at public stations.

Countries implementing electric car recharging networks are aware of the need to provide different types of stations so that all user needs can be met. Cumulative estimates of investments in public recharging stations by 2020 indicate levels of up to 2.4 million normal recharging stations and 6,000 rapid recharging stations for the countries in the EVI alliance (IEA, 2013).

\section{2 - Regulatory Models for Electric Mobility}

The implementation of a recharging infrastructure that satisfies the demands of electric vehicle users is directly related to current regulatory guidelines. This relationship stems from the fact that the regulatory framework defines possible business models. In general, the regulatory alternatives essentially vary at the level of liberalizing activities. Considering that the technical operation of recharging points and the marketing of electrical energy can be regarded as distinct activities and, at the same time, that recharging locations are diverse, the business opportunities for companies in the electrical sector vary greatly depending on the current regulations.

Within the scope of a regulated model, recharging infrastructure should be viewed as an expansion of the distributor's infrastructure. In this model, the technical operation of the recharging stations and the sale of energy for electric mobility is controlled by the distributor. However, it is expected that the electric vehicle owner will buy their residential recharging equipment, which will be their main recharging point. As for the recharging equipment located in private areas of public access, such as mall parking or fuel stations, the distributor is responsible for the stations' technical operation, along with selling the energy. Recharging stations are part of the distributor's regulatory base and are remunerated based upon a previously established rate of return. Likewise, the public recharging infrastructure belongs to the distributor and is included in its assets. The distributor is responsible for the recharging stations' technical operation, as well as selling energy for the public and semi-public recharging infrastructure (EURELECTRIC, 2013).

An intermediary scenario can be considered, where selling energy for electric mobility in public and semi-public places becomes a competitive business, envisioning the emergence of a new player, the electric mobility service provider, which offers a recharging service plus a range of new services to the end consumer (parking, car sharing, etc.). In this alternative model, the technical installation and operation of recharging 
stations in public and semi-public places is in the hands of the distributor, which is a regulated business. On the other hand, in private places, it is expected that consumers will buy their own recharging equipment and that the sale of energy will be carried out by the distributor.

In the "separate infrastructure" model, the recharging infrastructure is separate and independent of the value chain, which means that the recharging infrastructure is not part of the distributor's assets (EURELECTRIC, 2013). In this model, one can imagine the emergence of one or more technical operators of independent recharging infrastructure for public and semi-public places. These operators would ensure that the recharging networks would be freely accessible to all sellers of electricity for mobile energy ${ }^{21}$. The recharging infrastructure would be financed by network users, as a result of the compensation model chosen by the energy seller ${ }^{22}$. As for home recharging, the consumer could buy their own recharging equipment and energy sales could be under the control of the distributor ${ }^{23}$ or seller of energy for electric mobility, which can be supplied to both residential and public recharging.

Finally, a more liberalized market model, called "independent electric mobility," can be considered, where the emergence of a new agent is considered, the independent electric mobility service provider, which installs its own recharging network and provides the mobility service as part of an integrated offer, including a set of services for its customers (EURELECTRIC, 2013). It is then the responsibility of this agent to install a recharging network in semi-public and public places, in addition to the technical operation and the sale of energy for electric mobility. As in the previously mentioned model, the sale of energy for residential recharging may be taken over by the distributor ${ }^{23}$ or by the electric mobility service provider itself.

Thus, the regulated requirements for public and semi-public areas are minimal, such as the standardization of the recharging model. The main advantage of this model is to foster competition among the potential players in this market, as well as encouraging the development of new business models linked to the recharging infrastructure ${ }^{24}$.

In general, there is a predilection for liberalized regulatory models in countries that are developing an electric vehicle recharging infrastructure. This option is premised on the expectation that competition will encourage the development of technical solutions and business arrangements that will enable the development of efficient infrastructure with lower costs. However, it is necessary to emphasize that these infrastructures are being installed in countries where a great dissemination of electric vehicles is expected, due to the need to reduce the environmental impacts of the transportation sector. Therefore, electric mobility tends to be an important business for companies in the electricity sector.

\footnotetext{
${ }^{21}$ Agreements between the operators of recharging infrastructures and the sellers of electric mobility are implemented through business to business (B2B) contracts. To facilitate the energy and financial balances between these different agents, a clearing house platform is expected to emerge, aimed at ensuring proper functioning and transactional transparency in the market.

${ }^{22}$ The contract may include an energy component, where the consumer pays according to their level of consumption. On the other hand, a contract that includes a fixed monthly amount may also be established; the amount is chosen by the seller and is independent of consumption level. In fact, since the technical operator of the recharging infrastructure and the seller of energy for electrical mobility are separate entities in this model, the network operator charges the energy seller a fee for access to the charging equipment, which makes the final rate of electricity for electric mobility more expensive than the regulated rate.

23 Considering a regulated model where energy distribution and sale are vertically integrated. On the other hand, within a deverticalized model, selling energy to the captive consumer is free, under the control of the retail supplier of electric energy.

${ }^{24}$ Although the liberalized model has advantages, such as the fact that the model does not impact the energy rate, since the energy consumer will not pay for this infrastructure, this model may not be sufficient to enable the necessary recharging infrastructure in underdeveloped markets, as in the case of Brazil. This challenge mainly exists in public and semi-public places. The implementation of a liberalized model in these markets can result in companies not investing in the implementation of the recharging infrastructure to a degree that is sufficient for the viability of electric mobility.
} 
At the same time, the electricity sectors of these countries already display a considerable degree of liberalization.

\section{3 - The Case of Brazil}

The attractiveness of electric mobility for companies in the Brazilian electricity sector must be considered with reservations. This is because the Brazilian light vehicle fleet has a unique composition in terms of energy supply, and the regulatory framework in the Brazilian electricity sector tends to limit the business models to be implemented. Thus, any analysis of the potential market for electric vehicles in Brazil, as well as of business opportunities, first requires a description of the Brazilian light vehicle fleet and the regulatory guidelines of the electricity sector.

\section{1 - Characteristics of and Prospects in the Light Vehicle Fleet}

The Brazilian transportation sector presents a predominance of road transportation. In terms of light vehicles, the fleet included approximately 31 million vehicles in 2013. Nevertheless, a considerable increase in the fleet is expected, due to the increase in family income and the competitiveness of the internal market; this has been reflected in the Brazilian car market, which is already the fourth largest in the world, having sold 2.8 million vehicles in 2013 (ANFAVEA, 2014; EPE, 2014). Based on new vehicle sales estimates for the coming years and the rate of scrapping existing vehicles, it is possible to accept the hypothesis that the Brazilian light vehicle fleet will include approximately 56 million vehicles in 2030 (BORBA, 2012; EPE).

The energy supply of the Brazilian light vehicle fleet is quite unique because of the largescale use of ethanol, whether it is mixed with gasoline at rates of between $20 \%$ and $25 \%$, or simply as a final fuel (XXX). Flex fuel vehicles ${ }^{25}$ currently represent more than $60 \%$ of the fleet and $96 \%$ of all marketed vehicles. It is therefore understandable why gasoline consumption was 34 billion liters in 2013 and ethanol consumption was 22 billion liters ${ }^{26}$ (EPE, 2014).

Although Brazilian ethanol production has been stagnate in recent years, decreasing the share of ethanol in the supply of vehicles, it is worth noting that this stagnation is due to the financial crisis that the sector is experiencing. It therefore has a cyclical character. The potential for an expansion of ethanol production in Brazil is reasonable. DANTAS (2013) expects XX billion liters to be produced in 2030, while LEITE et al. (2009) calculate that it might be possible to produce 102 billion liters of ethanol using less than $7 \%$ of Brazil's arable land. Added to this is the potential for lignocellulosic ethanol production from bagasse and sugar cane straw.

The large-scale use of ethanol in the light vehicle fleet causes this fleet's carbon emissions to be XXX per km driven, compared to XYZ in European Union countries and XXX in the US. Since reducing greenhouse gas emissions is one of the main drivers of investment in electric mobility, it is evident that the spread of electric vehicles in Brazil does not have the same level of importance found in other countries. However, this does not mean that they will not be included in the Brazilian fleet and that they cannot ultimately contribute to maintaining the sustainable character of the Brazilian energy matrix. In particular, the

\footnotetext{
${ }^{25}$ These vehicles are characterized by the possibility of being fueled by ethanol and/or gasoline in any proportion. The introduction of these vehicles in the Brazilian fleet made the Brazilian fuel market more flexible and was fundamental in increasing the demand for hydrated ethanol to the extent that it incentivized consumers to acquire this type of vehicle, without fearing a lack of ethanol, which would have hindered the sales of vehicles fueled by ethanol, particularly after the rationing that took place at the end of the 1980s.

${ }^{26}$ Ethanol consumption is the sum of gasoline added to anhydrous ethanol, with 11 billion liters of hydrated ethanol used as a final fuel.
} 
inclusion of PHEV vehicles in the fleet tends to be an interesting strategy, in that it can enable the fueling of vehicles with electricity and ethanol, with a consequent reduction in gasoline use (BARAN and LEGEY, 2012).

\section{2 - The Regulatory Model of the Brazilian Electricity Sector}

Brazil is a country of continental dimensions that possesses a large-scale electrical system in terms of generation capacity and extent of the transmission system; the predominance of hydroelectric generation in its matrix is a striking feature that causes it to be centralized, and there is a segmentation among the operative and commercial spheres (REGO and PARENTE, 2013).

In this context, implementing market for energy is highly questionable, not only because the price of energy is characterized by extreme volatility, but mainly because it has a low level most of the time, since the marginal costs of a hydroelectric system are greatly reduced in years of normal hydrology. It is thus difficult to attract investment in order to expand the supply. Moreover, the failure of the liberalizing reforms implemented in the mid-1990s clearly illustrates the difficulty of establishing a market for energy (BAJAY, 2006).

Within the scope of the Brazilian electricity sector's current regulatory framework, it is evident that some of the guidelines implemented as part of the liberalizing reform of the 1990s are still present. For example, the production chain is deverticalized and the market includes the presence of independent power producers and free consumers. However, since the standards prioritize the security of supply, it has been established that the entire energy demand must be backed by consumption, in order to properly signal the expansion of demand (MORENO et al., 2010).

More than that, the energy market has been split into two segments. On the one hand, there is the regulated contract environment, where distributors acquire the energy necessary to serve their captive consumers through the following dynamic: the distributors state the expected demand, and energy auctions are held in order to contract the energy required by the pool of distributors. These auctions occur in reverse format, so as to encourage contracting at low prices. These auctions are also characterized by longterm contracts established between the distributors and the winners. Since they have fixed prices corrected according to an inflation index, these contracts eliminate the investors' exposure to the volatility of energy prices inherent in the Brazilian electrical system, and therefore become fundamental for the expansion of the sufficient and predictable supply of energy. However, the free market is where energy producers and free consumers can transact energy freely (TANKHA, 2008; ROCK and GARCIA, 2006).

Brazilian law provides the right to choose an energy supplier to consumers with a demand exceeding $3 \mathrm{MW}$ or those with a demand between $500 \mathrm{~kW}$ and $3 \mathrm{MW}$ who acquire energy from renewable sources, the latter being called free incentivized consumers. Therefore, the eligibility criteria in Brazil are strict when compared to those of a number of countries that have also conducted liberalizing reforms; it is thus clear why the Brazilian free market only represents $25 \%$ of the load.

\section{4 - Scenarios for Electric Mobility in Brazil}

As in the rest of the world, the inclusion of electric vehicles in the light vehicle fleet in Brazil is accompanied by great uncertainty. It is therefore not an easy task to estimate the impact of this inclusion on the Brazilian electrical system. In situations characterized by the presence of non-measurable uncertainty, the development of scenarios is an important 
analytical tool because it allows the possible trajectories of the question under consideration to be defined, i.e., it represents different future possibilities (SCHNAARS, 1987; POSTMA et al., 2012; SWART et al., 2004).

Since the goal here is to examine the impacts on the electricity sector in 2030, the size of the light vehicle fleet, the average distance traveled, the efficiency of the vehicle, and the recharging characteristics are assumed as data. The focused uncertainty variable is the share of electric vehicles in the light vehicle fleet in 2030, in order to measure the incidental consequences in the Brazilian electricity sector.

In line with Subsection 3.1, the Brazilian light vehicle fleet will be 56 million vehicles in 2030, while the average annual distance traveled by the respective vehicles will be 12,000 $\mathrm{km}$ (BORBA, 2008; IEA, 2009). In terms of energy consumption, it will be assumed that an electric vehicle would travel $4.7 \mathrm{~km} / \mathrm{kWh}$, while a PHEV would travel $4.4 \mathrm{~km} / \mathrm{kWh}^{27}$. In turn, vehicle recharging occurs at the owners' own residence $85 \%$ of the time, according to estimates from the EV Project (ECOTALITY, 2013).

If worldwide estimates point to a share of up to $4 \%$ pure electric vehicles in the light vehicle fleet in 2030, the characteristics of the Brazilian fleet make the adoption of more modest scenarios relevant, with a predominance of PHEV vehicles over BEVs. In this respect, based on the EPE (2014) and the IEA $(2011)^{28}$, three scenarios were constructed for the penetration of electric vehicles in Brazil in the time horizon of the 2030s.

In the reference scenario ${ }^{29}$, it is assumed that PHEVs and BEVs will account for $4 \%$ and $0.5 \%$ of the light vehicle fleet, respectively. Thus, the fleet of electric vehicles that can be connected to the network would be 2.53 million vehicles, and the energy demand of these vehicles would be around 6.85 TWh. In a more conservative scenario ${ }^{30}$, the share of PHEVs in the light vehicle fleet would be $2 \%$, while that of BEVs would be $0.5 \%$. Together, these vehicles would total 1.41 million units and have an energy consumption of approximately $3.79 \mathrm{TWh}$. On the other hand, the optimistic scenario ${ }^{31}$ is one where PHEVs and BEVs represent $9 \%$ and $3 \%$ of the light vehicle fleet, respectively. Consequently, the fleet of 6.75 million vehicles results in an energy consumption of 18.1 TWh. Table 2 summarizes the results obtained:

Table 2 - Scenarios for Vehicle Electrification in Brazil for 2030

\begin{tabular}{lccc} 
& $\begin{array}{c}\text { Conservative } \\
\text { Scenario }\end{array}$ & $\begin{array}{c}\text { Reference } \\
\text { Scenario }\end{array}$ & $\begin{array}{c}\text { Optimistic } \\
\text { Scenario }\end{array}$ \\
\hline & & & \\
PHEV stock in the total fleet (millions) & 1.12 & 2.25 & 5.06 \\
EV stock in the total fleet (millions) & 0.28 & 0.28 & 1.69 \\
PHEV/EV stock in the total fleet (millions) & $\mathbf{1 . 4 1}$ & $\mathbf{2 . 5 3}$ & $\mathbf{6 . 7 5}$ \\
Share of PHEV in the total fleet (\%) & $2.00 \%$ & $4.00 \%$ & $9.00 \%$
\end{tabular}

\footnotetext{
${ }^{27}$ Estimates of energy consumption consider that PHEVs are operating in the electric mode.

${ }^{28}$ EPE (2014) presents estimates of the evolving Brazilian energy demand until 2050. The issue of electric vehicles is addressed in the part related to the light vehicle fleet. In turn, the IEA has published documents regarding the outlook for electric mobility on an international level. Among these publications, the Roadmap published in 2011 deserves particular mention for the purposes of developing these scenarios.

${ }^{29}$ The reference scenario is based on forecasts by the EPE (2014), envisioning a $4 \%$ share of hybrid vehicles and a $0.5 \%$ share of pure electric vehicles in the light vehicle fleet by 2030 . However, since the share of plug-in vehicles was not clearly specified by the EPE (2014), it was considered in this scenario that all hybrid vehicles can be connected to the power grid.

${ }^{30}$ In the conservative scenario, the authors estimated that only $2 \%$ of hybrid vehicles would be plug-in. On the other hand, a $0.5 \%$ share of pure electric vehicles in the light vehicle fleet is estimated.

${ }^{31}$ The optimistic scenario was developed based on forecasts by the IEA (2011), which foresees a $9 \%$ share of plug-in hybrid vehicles and a 3\% share of pure electric vehicles in the light vehicle fleet for the year 2030.
} 
Share of EV in the total fleet (\%)

Share of PHEV/VE in the total fleet (\%)

Energy consumption of PHEVs (TWh)

\section{Sources: EPE (2014) and IEA (2011).}

The development of scenarios for electric mobility in Brazil is also relevant for designing the recharging infrastructure needed to service electric vehicles. In this sense, through a bottom-up approach, data concerning the installation of recharging stations were estimated from the scenarios developed, the results of which are shown in Table $3^{32}$. In this study, only Level II and Level III stations have been considered, since Level I recharging involves a standard outlet without any adaptation of the network and does not require any investment by the consumer.

To determine the number of recharging stations equivalent to electric vehicles included in the fleet, estimates by the IEA (2013) and SCHEY (2013) were considered. Thus, 0.76 Level II stations per electric vehicle, 0.08 public Level II stations per electric vehicle and 0.01 Level III stations per electric vehicle were considered. Regardless of the scenario considered, the considerations listed in this paragraph result in $89.4 \%$ of the installed stations being residential Level II, $9.4 \%$ being public Level II, and $1.2 \%$ being Level III stations.

At the same time, it is important to consider the investment costs of this infrastructure, based on the cost data presented in Section 2.1, estimating not only the cost of the recharging equipment, but also the different technical devices to be installed along with the recharging equipment, as well as planning and device installation $\operatorname{costs}^{33}$. Table 3 incorporates the costs of the previously established Level II and Level III stations and evaluates the cost of the investments to be made in the three scenarios considered.

Table 3 - Scenarios for Installing Electric Vehicle Recharging Stations for 2030

\begin{tabular}{lccc} 
& $\begin{array}{c}\text { Conservative } \\
\text { Scenario }\end{array}$ & $\begin{array}{c}\text { Reference } \\
\text { Scenario }\end{array}$ & $\begin{array}{c}\text { Optimistic } \\
\text { Scenario }\end{array}$ \\
\hline & & & \\
Number of residential Level II stations (millions) & 1.07 & 1.92 & 5.11 \\
$\begin{array}{l}\text { Number of non-residential Level II stations (millions) } \\
\text { Number of non-residential Level III stations }\end{array}$ & 0.11 & 0.20 & 0.54 \\
(millions) & 0.01 & 0.03 & 0.07 \\
$\begin{array}{l}\text { Total number of electric vehicle recharging stations } \\
\text { (millions) }\end{array}$ & 1.19 & $\mathbf{2 . 1 5}$ & $\mathbf{5 . 7 2}$ \\
$\begin{array}{l}\text { Residential Level II CAPEX stations (billion USD) } \\
\text { Non-residential Level II CAPEX stations (billion USD) }\end{array}$ & 2.46 & 4.43 & 11.82 \\
Non-residential Level III CAPEX stations (billion USD) & 0.96 & 1.73 & 4.62 \\
\end{tabular}

\footnotetext{
${ }^{32}$ In this study, only Level II and III stations were considered, since Level I recharging involves a standard outlet without any adaptation of the network and does not require any investment by the consumer.

${ }^{33}$ As estimated in Table 2 of the second section, the investment cost for a residential Level II recharging station would be USD 2,300, while it would be about USD 8,600 for a public Level II recharging station and USD 34,500 for a Level III station.
} 


\section{Sources: EPE (2014), IEA (2011; 2013), SCHEY (2013).}

According to Table 3, 2.15 million recharging points would be installed in the reference scenario $^{34}$, with the number of installed points being 1.19 million and 5.72 million, respectively, in the conservative and optimistic scenarios. Within this reference scenario, 1.92 million residential Level II electrical posts, 200,000 public Level II recharging stations, and 25,000 Level III recharging stations are expected to be installed. Similarly, Table 3 shows that the cost of investment in the reference scenario would be US\$ 7.04 billion $^{35}$, which would be US\$ 3.91 billion in the conservative scenario and US\$ 18.78 billion in the optimistic scenario.

In short, it can be said that in Brazil, based on the study in Table 3 as well as on international experience, it is reasonable to assume that residential recharging will be predominant and will represent about $85 \%$ of total recharges (SCHEY, 2013).

\section{5 - Financial Attractiveness of Electric Mobility for a Company in the Brazilian Electricity Sector}

The results obtained in Section 4 indicate that the electric mobility market will not represent major impacts on electric energy consumption in Brazil. As an illustration, even the consumption of $18.1 \mathrm{TWh}$ in the optimistic scenario indicated in Table 2 would represent less than $2 \%$ of the 965 TWh projected for consumption in 2030 by the EPE (2014). As a result, selling energy for electric mobility does not seem to be a very important business.

It can thus be seen that corporate interest in the sector tends to be in the exploitation of recharging stations. According to the results reported in Table 3, it is expected that investments in recharging infrastructure will reach a level of $\mathrm{R} \$ 7.04$ billion for the reference scenario, representing a non-negligible investment for investment players in the market. However, most of this total, i.e., R\$ 4.43 billion (representing 63\% of the forecasted total), is directly associated with the acquisition of recharging equipment by the consumers themselves and, therefore, does not constitute an investment for players in the electrical sector ${ }^{36}$.

In this context, the investments to be made by companies in the electrical sector are restricted to a universe of $\mathrm{R} \$ 2.6$ billion until 2030, according to the reference scenario defined in Table 3. Considering that the market model to be implemented in Brazil tends to be regulated ${ }^{37}$, it is expected that investments in recharging infrastructure will be remunerated by the regulatory WACC. A comparison of these investments with the

\footnotetext{
${ }^{34}$ Within this reference scenario, there are plans to install 1.7 million residential Level II electrical stations, 180,000 public Level II recharging stations, and 20,000 Level III recharging stations.

${ }^{35}$ The investment will be divided between US\$ 3.94 billion for residential electrical stations, US\$ 1.54 billion for public Level II electrical stations, and US 780,000 for Level III stations. It is thus interesting to note that, although the residential electrical stations constitute $89.4 \%$ of the total stations, they represent only $62.9 \%$ of the total investment. On the other hand, the Level III stations represent only $1.2 \%$ of all the installations, but $12.5 \%$ of the total investment. This stems from the considerable investment for a CHadEMO Level III station, which can cost up to US\$34,500, while the residential Level II electrical stations represent an investment of only US\$2,300.

${ }^{36}$ Companies in the electricity sector are likely to be involved in providing services (installing and maintaining charging stations) in this market segment.

${ }^{37}$ On October 30, 2013, the Mines and Energy Commission of the House of Representatives approved a proposal that requires energy utilities to install recharging points for electric car batteries near public parking spaces. The proposal also states that it will be the responsibility of the executive branch to create incentives for installing outlets for recharging these vehicles in the garages of residential buildings. In the same direction, the regulation for recharging points at conventional fuel stations is already being addressed.
} 
regulatory remuneration base (or RRB) and the net remuneration base ${ }^{38}$ (or NRB) of 64 Brazilian distributors provides a solid theoretical foundation for estimating the relative weight of the electric mobility business for market players. Thus, the $\mathrm{R} \$ 2.6$ billion to be invested in stations located in public and semi-public areas represent, respectively, $2.1 \%$ of the RRB and $4.2 \%$ of the NRB, according to data published by ANEEL (2015) for the latest tariff revision cycle ${ }^{39}$. Even in the optimistic scenario, the amount to be invested represents only $5.7 \%$ and $11.2 \%$ of the RRB and the NRB, respectively. Therefore, these estimates support the idea that the electric mobility business tends to be a small business restricted to one distributor in the industry, as it would represent a limited portion of its assets.

In the context of more liberalized models, the market can also be seen as relatively small. The logic behind market liberalization is the establishment of a competitive market in which the rate of return tends to be equal to the cost of capital. However, given that investment in recharging infrastructure will take place at a time prior to the spread of the electric vehicle fleet, investors in liberalized models will face a risk in making the investment. Therefore, in addition to representing a limited opportunity for the company, there is great uncertainty about the viability of the business.

\section{$6-$ Conclusion}

The unique characteristics of the Brazilian light vehicle fleet, with the high share of flex fuel vehicles in the total fleet and the lack of tax incentives to facilitate the purchase of electric vehicles prevent the expansion of electric models from occurring at an accelerated rate. Thus, the consumption projections for electric vehicles show that selling energy for electric mobility will not be a relevant business in the medium term.

On the other hand, it was pointed out that market models define the business models to be implemented. In this context, Brazil tends to adopt a model presenting a more regulated character, corroborating the latest measures taken by the government. However, as most of the investment is associated with the residential recharging equipment, it can be concluded that, regardless of whether or not the business model is important for the company, in the liberalized model, there is still an inherent risk to investment for the entrepreneur.

\section{Acknowledgements}

This article is one of the results of the "Energy in the City of the Future" project produced by CPFL Energia with funds from the ANEEL research and development program. The authors are grateful for the support provided, which funded this research.

\footnotetext{
${ }^{38}$ The regulatory remuneration base (RRB) represents, on the one hand, all the fixed assets in service, valued and depreciated, but also the operational warehouses, deferred tax assets and special obligations (ANEEL, 2010). In turn, the net remuneration base (NRB) is obtained by subtracting the assets depreciated in relation to the RRB, i.e., it represents the assets that generate remuneration for that company.

${ }^{39}$ According to ANEEL (2015), in the latest tariff review cycle, the RRB of 64 distributors is estimated at around R\$122.5 billion and the NRB is estimated at around $\mathrm{R} \$ 61.9$ billion.
} 


\section{Bibliography}

BARAN R., A Introdução de Veículos elétricos no Brasil: avaliação do impacto no consumo de gasolina e eletricidade, Tese de Doutorado, PPE/COPPE/UFRJ, Rio de Janeiro, 2012.

BORBA B. S. M. C., Modelagem Integrada da Introdução de Veículos Leves Conectáveis à Rede Elétrica no Sistema Energético Brasileiro, Tese de Doutorado, PPE/COPPE/UFRJ, Rio de Janeiro, 2012.

DIAS M. V. X., HADDAD J., BORTONI E. Da C., NOGUEIRA L. A. H., Impacto no consumo de energia elétrica e nas emissões decorrente da entrada de carro elétricos na frota de automóveis do estado de São Paulo, IX CBPE, Florianópolis, 25 a 27 de Agosto de 2014.

DIJK M., ORSATO R. J., KEMP R., The emergence of an electric mobility trajectory, Energy Policy 52 (2013), pp. 135-145.

ECOTALITY, The EV Project - Quarter 2, 2013 quarterly report, ECOTALITY North America, Phoenix, 2013.

EGBUE O., LONG S., Barriers to widespread adoption of electric vehicles: An analysis of consumer attitudes and perceptions, Energy Policy 48 (2012), pp. 717-729.

ETEC, Electric Transportation Engineering Corporation, Electric Vehicle Charging Infrastructure Deployement Guidelines for the Greater San Diego Arena, ETEC, San Diego, 2010

ETEC, Electric Transportation Engineering Corporation, Q2 2013 Report - The EV Project, ETEC, Phoenix, 2013.

EPE, Empresa de Pesquisa Energética, Plano Nacional de Energia-Demanda de energia 2050, Rio de Janeiro, Agosto de 2014.

IEA, International Energy Agency, Transport, Energy and $\mathrm{CO}_{2}-$ Moving Toward Sustainability, IEA, Paris, 2009.

IEA, International Energy Agency, Technology Roadmap: Electric and plug-in hybrid electric vehicles, IEA, Paris, 2011.

IEA, International Energy Agency, Energy Technology Perspectives 2012 - Pathways to a Clean Energy System, IEA, Paris, 2012a.

IEA, International Energy Agency, World Energy Outlook 2012, IEA, Paris, 2012b.

IEA, International Energy Agency, World Energy Outlook 2013, IEA, Paris, 2013.

IEA, International Energy Agency, Energy Technology Perspectives 2014 - Harnessing Electricity's Potential, IEA, Paris, 2014.

ICCT, The International Council on Clean Transportation, Passenger vehicle greenhouse gas and fuel economy standards: A global update, ICCT, Washington DC, 2007.

IPI, International Parking Institute, 2011. Parking Industry Ready to Answer the Charge in President Barack Obama's State of the Union Address for 1 Million Electric Cars by 2015. IPI. US. 
KEMPTON W., TOMIĆ J., Vehicle-to-grid power implementation: From stabilizing the grid to supporting large-scale renewable energy, Journal of Power Sources 144 (2005), pp. 280-294.

MIDLER C., BEAUME R., Project-based learning patterns for dominant design renewal: The case of the electric vehicle, International Journal of Project Management 28 (2010), pp. 142-150.

NATIONAL RESEARCH COUNCIL, Overcoming Barriers to Electric-Vehicle Deployment - Interim Report. Washington DC: National Academy of Sciences, 2013.

SAE, Hybrid Committee, SAE Charging Configurations and Ratings Terminology, SAE International. Warrendale, 2012.

SCHROEDER A., TRABER T., The economics of fast charging infrastructure for electric vehicles. Energy Policy 43 (2012), pp. 136-144.

SMITH C. B., Análise da Difusão de Novas Tecnologias Automotivas em prol da Eficiência Energética na Frota de Novos Veículos Leves no Brasil, Tese de Doutorado, PPE/COPPE/UFRJ, Rio de Janeiro, 2010.

WILLS W., LA ROVERE E.L, Light vehicle energy efficiency programs and their impact on Brazilian $\mathrm{CO}_{2}$ emissions, Energy Policy 38 (2010), pp. 6453-6462.

XU, H., MIAO, S., ZHANG, C., SHI, D., Optimal placement of charging infrastructures for large-scale integration of pure electric vehicles into grid, Electrical Power and Energy Systems 53 (2013), pp. 159-165. 